\title{
A comparison of the body-water and nitrogen balance-sheet methods for determining the nutritive value of proteins
}

\author{
By KATHLEEN M. HENRY AND JOYCE TOOTHILL \\ National Institute for Research in Dairying, Shinfield, Reading
}

(Received I8 August 196I-Revised 24 October 1961)

Biological methods available for determining the nutritive value of proteins have recently been reviewed by Allison (1955), Bender (1958) and Adrian \& Rerat (1958), and several reports of comparisons between methods for the evaluation of selected proteins have appeared (Rutger's University: Bureau of Biological Research, 1950; Forbes \& Yohe, I955; Chapman, Castillo \& Campbell, 1959; Rippon, I959; Tomarelli, Minnick, d'Amato \& Bernhart, r959). It is generally agreed (Forbes \& Yohe, 1955; Bender, 1958; Rippon, 1959) that the balance-sheet method of Mitchell (Mitchell, 1923-4; Mitchell \& Carman, I926), measuring the biological value and true digestibility of proteins, gives more fundamental information and is more precise than other available methods. This method has been in use in this laboratory for many years and has been preferred to the growth method of Osborne, Mendel \& Ferry (19I9) because of its greater precision, particularly for relatively small differences (cf. Henry, Kon, Lea \& White, 1947-8). It is, however, time-consuming, and the method, based on body-water determinations, described by Miller \& Bender (1955) seemed to offer a more rapid way of assessing Mitchell's (Mitchell \& Villegas, r923) net protein value (NPV), that is biological value $\times$ true digestibility $\div$ 100.

We have applied the method of Miller \& Bender (I955) to a series of thirty-five proteins or protein foods of different quality and compared the results with the NPV determined by the balance-sheet method. Before doing so it was necessary to establish, for our colony, the relationship between the age of the rat and the water and nitrogen content of its body. For this purpose two series of experiments were carried out, in the second of which the livers of the rats were analysed separately from the rest of the body, with a view to the possible application of the method to larger animals with which carcass analysis would be impracticable. In the second series some preliminary tests were also done to establish whether the ratio between body content of water and $\mathrm{N}$ was affected by dietary changes.

EXPERIMENTAL

\section{Animals}

Rats of our hooded Norwegian strain were used. They were weaned at $2 \mathrm{I}$ days on to our normal stock diet (McKinlay, r95I). 


\section{Experimental diets}

The basal 'protein-free' diet had the percentage composition: rice starch 64, sugar I2, potato starch Io, margarine fat Io, salts (de Loureiro, I93I) 4. In all experiments, the protein source replaced an equal weight of rice starch so that the diets contained about $8 \%$ protein. To each $\mathrm{kg}$ of diet were added: thiamine $3.3 \mathrm{mg}$, riboflavin $5.5 \mathrm{mg}$, pyridoxine hydrochloride $3.3 \mathrm{mg}$, calcium pantothenate $1 \mathrm{r} .0 \mathrm{mg}$, folic acid $0.6 \mathrm{mg}$, biotin $0.6 \mathrm{mg}, p$-aminobenzoic acid I $1.0 \mathrm{mg}$, nicotinic acid I $1.0 \mathrm{mg}$, inositol I $10.0 \mathrm{mg}$, choline hydrochloride $1900 \mathrm{mg}$, menaphthone (2-methyl-I,4-naphthaquinone) $2 \cdot 2 \mathrm{mg}$, cyanocobalamin $20 \mu \mathrm{g}$. The diets were given ad lib. In addition, 360 i.u. vitamin A, 26 i.u. vitamin D and $x^{*} 4 \mathrm{mg} \alpha$-tocopheryl acetate were given, in arachis oil, to each rat at the beginning of an experiment.

\section{Sources of proteins tested}

The protein foods tested included some that had been assessed by their effect on liver $\mathrm{N}$ content (Henry, Cormack \& Kosterlitz, 196r) and some selected protein concentrates collected for a collaborative study on protein quality organized by the Agricultural Research Council (Boyne, Carpenter \& Woodham, 1961). The conventional factors used for computing the protein content of the diet were $\mathrm{N} \times 6.38$ for egg, casein and milk and $\mathrm{N} \times 6.25$ for other proteins.

The following protein sources have already been described by Henry et al. (1961): vitamin-low casein (Genatosan Ltd), dried defatted egg, soya-bean meal (sample 5), isolated soya proteins (Drackett, Drackett Co, Cincinatti, Ohio), linseed meal, yeast, dried peas and wheat gluten. The Agricultural Research Council samples of fish meal ( $\mathrm{FM}_{4}, 6,17$ ), meat meal (MM IO, 18, 20), soya-bean meal (SB I, 3, 5), cottonseed

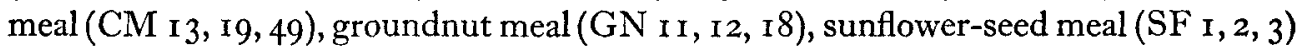
and dried skim milk (SM $3,7,8$, I $_{3}, 1_{19}, 29$ ) are described by Duckworth, Woodham \& McDonald (196r). The 'control' and 'stored' milks have been described by Henry \& Kon (1952). These milks contained $7.5 \%$ moisture and had been kept in cold storage $\left(0-3^{\circ}\right)$; the 'stored' milk had previously been stored at $37^{\circ}$ for 60 days. Such treatment reduces the nutritive value of the proteins because of inactivation of some of the lysine brought about by a Maillard reaction between it and lactose (cf. Henry et al. 1947-8).

\section{Determination of the $N$ :water ratio in carcasses and livers}

In each of two series of experiments forty-two rats were maintained on the stock diet from weaning until they were $36-42$ days old. This age range was chosen as it covered that portion of the response curve to be used in subsequent experiments (see p. 127). Three male and three female rats (unrelated) were killed at $36,37,3^{8,39}, 40,4 \mathrm{I}$ and 42 days of age. In the second series of experiments, to test the effect of diet, littermates (two males and two females) of the rats killed when 38 days old were given the 'protein-free' diet or one containing $8 \%$ protein as casein for Io days (the normal experimental feeding period, see p. 127) before they were killed, also at 38 days of age. 


\section{Body-zoater determination}

The rats were killed by coal-gas and the entire rat was placed in a large evaporating dish; the skull was pierced and the abdominal and thoracic cavities were opened as recommended by Miller \& Bender (1955). The bodies were dried in an air oven at 100-10 $5^{\circ}$ for $48 \mathrm{~h}$ initially and thereafter for $2 \mathrm{~h}$ periods until there was no further loss of weight. In the second series of experiments livers were removed and dried separately from the rest of the body.

\section{Body-and liver- $N$ determination}

In both series of experiments $\mathrm{N}$ was determined by the macro-Kjeldahl method after digestion.

First series. The dry carcasses were divided into three or four approximately equal portions and digested with Io $\mathrm{ml}$ conc. $\mathrm{H}_{2} \mathrm{SO}_{4} / \mathrm{g}$ dry carcass. The method proved troublesome as considerable frothing occurred, and analyses could not be completed for four out of the forty-two rats used.

Second series. An adaptation of the method described by Rippon (1959) was used. The dry carcass was put into a $\mathrm{I} 1$. conical flask with $300 \mathrm{ml}$ conc. $\mathrm{H}_{2} \mathrm{SO}_{4}$; after Io min $200 \mathrm{ml}$ water were added and the mixture was allowed to stand overnight. By the next morning the carcass was usually nearly dissolved and solution was completed by warming on a water-bath. The solution was then transferred to a 21 . conical flask and the volume made up with water to about $1700 \mathrm{ml}$, and a black tarry residue was dissolved with a further $100 \mathrm{ml}$ conc. $\mathrm{H}_{2} \mathrm{SO}_{4}$. After the solution had again stood overnight it was filtered through glass wool into a 21 . volumetric flask and made up to volume. The slight black residue on the glass wool was discarded as it was found to contain no measurable amount of $\mathrm{N}$. The dried livers were put into $250 \mathrm{ml}$ conical flasks with $30 \mathrm{ml}$ conc. $\mathrm{H}_{2} \mathrm{SO}_{4}$ and, after they had stood for $10 \mathrm{~min}, 20 \mathrm{ml}$ water were added. If solution was incomplete after further standing overnight it was rapidly completed by heating on the water-bath. The solution was then made up to $25^{\circ} \mathrm{ml}$ in a volumetric flask. Suitable portions of both the carcass and liver solutions were digested by the procedure described by Henry, Kon \& Watson (1937) for urine with the modification that the amount of $\mathrm{K}_{2} \mathrm{SO}_{4}$ added was doubled, selenium oxychloride was added as catalyst and digestion was continued for $2 \mathrm{~h}$ after the solution had turned clear green.

\section{Determination of the net protein utilization (NPU) by estimation of body water in rats}

The NPU (Miller \& Bender, 1955) and net protein retention (NPR) (Bender \& Doell, 1957) were determined at an $8 \%$ level of protein intake for a total of thirty-five proteins or protein foods. In each test four litters of three male and three female rats, aged $27-32$ days, were used. They were divided into six groups of four rats (two male and two female) so that each group contained one rat from each litter. The rats were so distributed that the total weights of each group did not differ by more than I-2 g. One group was given the 'protein-free' diet, one the casein (reference protein) diet and the remaining four groups one of the other test proteins. Each experiment lasted 
for 1o days. Rats were housed, fed and analysed separately, but values for the four rats in each group were pooled for the calculations (cf. Miller \& Bender, 1955). Duplicate determinations were done on all samples, and if the values for NPU did not agree within four units further replicates were done (Miller \& Bender, private communication).

\section{Determination of the biological value and true digestibility of proteins by the balance-sheet method}

The biological value and true digestibility of the protein preparations were determined by the balance-sheet method of Mitchell (Mitchell, 1923-4; Mitchell \& Carman, 1926). Groups of twelve female rats aged 25-26 days were used in all tests. Details of the cages and experimental procedure are given elsewhere (Henry et al. 1937; Henry et al. 1947-8; Henry \& Kon, 1956). In most of the tests casein was included as a reference protein.

\section{RESULTS AND DISCUSSION}

Table I gives mean values, for the two series of experiments, for the percentage of $\mathrm{N}$ and water and for the ratio of these two components in the carcasses of male and female rats aged $3^{6-42}$ days. Analysis of variance showed that the age of the rats influenced the percentage of $\mathrm{N}(P<0.05)$ and the ratio of $\mathrm{N}$ to water $(P<0.00 \mathrm{I})$, that males had a lower ratio than females $(P<0.05)$, but that there was no evidence of a sex $\times$ age interaction. In agreement with the findings of Bender \& Miller (1953) and of Dreyer (1957), the body $\mathrm{N}$ : water ratio increased significantly with the age of the rat. In agreement with Dreyer but not with Bender \& Miller, we found a significant sex effect. Consequently in all assays we have used equal numbers of each sex.

The relationship between this ratio and the age of the rats can be expressed by the equations:

(a) $y=0.034 x+2.63, r=0.44$ for males,

(b) $y=0.034 x+2.71, r=0.45$ for females,

where $x=$ age of rat in days, $y=(\mathrm{N} \times 100)(\%) \div \mathrm{H}_{2} \mathrm{O}(\%)$ for carcass of rat. In groups with equal numbers of males and females the constant would be the mean of those for the separate sexes. These correlation coefficients agreed well with that of 0.42 reported by Bender \& Miller (1953) for hooded Norwegian rats aged 33-57 days; moreover, their ratio of 3.8 for $\mathrm{N}$ : water is very similar to our mean value of $4^{\circ} \mathrm{O}$

Table I. Mean values for nitrogen and water content of carcasses of rats reared on a stock diet until they were $36-42$ days old

\begin{tabular}{lccc}
\multicolumn{1}{c}{ Sex } & N (\%) & Water (\%) & $\begin{array}{c}\text { Ratio, } \\
\text { I0o N: water }\end{array}$ \\
$q$ & $2 \cdot 78(39)$ & $69.4(42)$ & $4 \cdot 02(39)$ \\
$\circ$ & $2 \cdot 75(41)$ & $69.8(42)$ & $3.95(41)$ \\
\% and $\delta$ & $2 \cdot 77(80)$ & $69.6(84)$ & $3.99(80)$
\end{tabular}

Figures in parentheses are the number of rats. 
Table 2. Mean values with their standard errors for nitrogen and water content of whole carcasses and of livers of twenty-one female and twenty-one male rats reared on a stock diet until they were $3^{6-42}$ days old
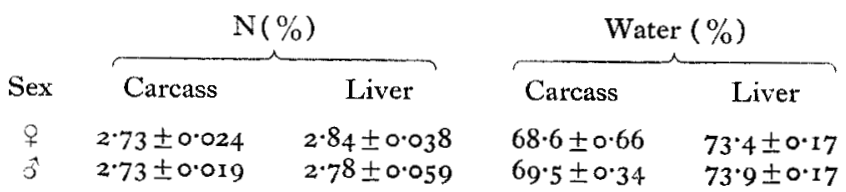

$\begin{array}{cc}\overbrace{\text { Carcass }}^{\text {Ratio, I00N:water }} \\ \begin{array}{ll}\text { Liver } \\ \text { 4.01 } \pm 0.037\end{array} \\ 3.93 \pm 0.032 & 3.77 \pm 0.051\end{array}$

Table 3. Mean values for nitrogen and water content of whole carcasses and of livers of groups of six litter-mate rats (three female and three male) maintained on a stock diet until they were 28 days old and then given, for Io days, the stock diet, a N-free diet or a diet containing $8 \%$ protein as casein

\begin{tabular}{|c|c|c|c|c|c|c|}
\hline \multirow[b]{2}{*}{ Diet } & \multicolumn{2}{|c|}{$N(\%)$} & \multicolumn{2}{|c|}{ Water (\%) } & \multicolumn{2}{|c|}{ Ratio, $100 \mathrm{~N}$ : water } \\
\hline & Carcass & Liver & Carcass & Liver & Carcass & Liver \\
\hline $\begin{array}{l}\text { Stock } \\
\text { N-free } \\
\text { Casein }\end{array}$ & $\begin{array}{l}2 \cdot 71 \\
2 \cdot 81 \\
2 \cdot 83\end{array}$ & $\begin{array}{l}2 \cdot 85 \\
2 \cdot 27 \\
2 \cdot 42\end{array}$ & $\begin{array}{l}68 \cdot 8 \\
66 \cdot 0 \\
66 \cdot x\end{array}$ & $\begin{array}{l}73 \cdot 4 \\
74 \cdot 1 \\
74 \cdot 6\end{array}$ & $\begin{array}{l}3 \cdot 94 \\
4 \cdot 26 \\
4 \cdot 28\end{array}$ & $\begin{array}{l}3.89 \\
3.06 \\
3.25\end{array}$ \\
\hline $\mathrm{SE}(\mathrm{IO} \mathrm{df})$ & \pm 0.057 & \pm 0.072 & \pm 0.57 & \pm 0.45 & \pm 0.073 & \pm 0.101 \\
\hline
\end{tabular}

(Table I) for the bulked sexes. A much higher ratio of 4.8 is reported by Forbes $\&$ Yohe (1955) for albino rats aged about 28 days.

Table 2 gives mean values for the percentages of $\mathrm{N}$ and water and their ratios in the carcasses and livers of the rats used in the second series of experiments (see p. 127) and Table 3 gives the corresponding values for 38 -day-old rats that had been given, from 28 days of age, our stock diet, a 'protein-free' diet or one containing $8 \%$ protein as casein. The figures in Table 3 show that the bodies of rats given the stock diet contained a slightly, but significantly, higher concentration of water than those of littermates given the $\mathrm{N}$-free or $8 \%$ protein diets although the $\mathrm{N}$ concentrations did not differ significantly. Consequently a slight error is inherent in the values for the $\mathrm{N}$ content of the two latter groups calculated from their water content with the equations (p. 128) derived from values for rats given the stock diet. As the error will be the same for $\mathrm{N}$-free and $8 \%$ protein diets the results given below are not affected. de Muelenaere, Rayner \& Muller ( 1960 ) have concluded, from analyses of sixty male rats, that the error involved in calculating the content of $\mathrm{N}$ from that of water can be reduced if a multiple, instead of a linear, regression is used.

Methods for assessing the nutritive value of proteins by changes in liver $\mathrm{N}$ have been proposed (cf. Henry, Kosterlitz \& Quenouille, 1953). Table 3 shows that, although the concentration of $\mathrm{N}$ in the liver reflects the quantity of the protein, that of water is independent of dietary changes. Moreover, the correlation between the $\mathrm{N}$ : water ratio in liver and the age of the rat is very poor $(r=0 \cdot 16)$. It is evident, therefore, that protein quality cannot be predicted from determinations of the water content of the liver.

Table 4 gives the nutritive values of the thirty-five protein sources tested by the balance-sheet and body-water methods. In confirmation of the findings of Bender \& 
Doell (1957), NPU and NPR values obtained on the same rats were highly correlated $(r=0.98)$. The correlation between these two values and NPV was also excellent $(r=0.9 \mathrm{I}$ and 0.90 , respectively). Theoretically the figures obtained for NPV and NPU should be the same. It was so, however, only when lysine or lysine with cystine were

Table 4. Biological value (BV), true digestibility (TD), net protein value (NPV), net protein utilization (NPU) and net protein ratio (NPR) of thirty-five proteins or protein sources (see p. 126) grouped according to their limiting amino acid(s)

\begin{tabular}{|c|c|c|c|c|c|}
\hline \multirow[b]{2}{*}{ Protein source } & \multicolumn{2}{|c|}{ Balance-sheet method } & \multicolumn{2}{|c|}{ Body-water method } & \multirow{2}{*}{$\begin{array}{l}\text { Expected } \\
\text { limiting } \\
\text { amino } \\
\operatorname{acid}(\mathrm{s}) \ddagger\end{array}$} \\
\hline & $\mathrm{TD}^{*}$ & $\begin{array}{c}\mathrm{NPV} \\
(\mathrm{BV} \times \mathrm{TD} \div \mathrm{IOO})\end{array}$ & NPUt & NPRt & \\
\hline Egg (whole, defatted) & $95 \cdot 2 \pm 1 \cdot 24 \quad 97 \cdot 3 \pm 0 \cdot 47$ & $92 \cdot 6$ & $86 \cdot 6 \pm 2 \cdot 56(3)$ & $4 \cdot 56 \pm 0 \cdot 13(3)$ & \\
\hline $\begin{array}{l}\mathrm{SM}_{19} \\
\mathrm{FM}_{6} \\
\mathrm{SM}_{29} \\
\mathrm{SM}_{13} \\
\mathrm{SM}_{7} \\
\mathrm{SM}_{3} \\
\mathrm{SM}^{8} \\
\text { 'Control' milk } \\
\text { Casein (vitamin-low) } \\
\text { Dried brewer's yeast } \\
\text { FM } 4 \\
\text { MM } 8 \\
\text { FM } 8 \\
\text { MM } 70\end{array}$ & $\begin{array}{ll}94.6 \pm 1.31 & 94.4 \pm 0.60 \\
89.9 \pm 0.98 & 99.1 \pm 0.8 \mathrm{I} \\
88.9 \pm 0.59 & 93.2 \pm 0.36 \\
88.7 \pm 0.97 & 94.0 \pm 0.75 \\
87.3 \pm 0.97 & 93.1 \pm 0.75 \\
86.1 \pm 0.97 & 93.2 \pm 0.75 \\
85.8 \pm 1.31 & 90.6 \pm 0.60 \\
85.0 \pm 1.65 & 99.5 \pm 0.58 \\
84.3 \pm 0.89 & 99.0 \pm 0.2 \mathrm{I} \\
77.3 \pm 0.86 & 88.7 \pm 0.81 \\
72.6 \pm 0.98 & 78.0 \pm 0.81 \\
62.8 \pm 1.77 & 85.6 \pm 0.88 \\
60.6 \pm 0.98 & 89.1 \pm 0.8 \mathrm{I} \\
52.0 \pm \mathrm{I} .77 & 77.4 \pm 0.88\end{array}$ & $\begin{array}{l}89 \cdot 3 \\
89 \cdot 1 \\
82 \cdot 9 \\
83 \cdot 4 \\
81 \cdot 3 \\
80 \cdot 2 \\
77 \cdot 7 \\
84 \cdot 5 \\
83 \cdot 5 \\
68 \cdot 6 \\
56 \cdot 6 \\
53 \cdot 8 \\
54 \cdot 0 \\
40 \cdot 2\end{array}$ & $\begin{array}{l}72 \cdot 2 \pm 2 \cdot 84(6) \\
70 \cdot 9 \pm 1 \cdot 45(2) \\
74 \cdot 3 \pm 2 \cdot 78(6) \\
74 \cdot 5 \pm 2 \cdot 64(6) \\
73 \cdot 3 \pm 2 \cdot 51(6) \\
77 \cdot 2 \pm 2 \cdot 72(6) \\
71 \cdot 0 \pm 1 \cdot 44(3) \\
77 \cdot 0 \pm \mathrm{I} \cdot 47(4) \\
71 \cdot 0 \pm 0 \cdot 77(24) \\
55 \cdot 6 \pm 1 \cdot 84(6) \\
34 \cdot 3 \pm 2 \cdot 95(4) \\
43 \cdot 3 \pm 1 \cdot 83(3) \\
47 \cdot 1 \pm 0.35(2) \\
19 \cdot 3 \pm 4 \cdot 61(4)\end{array}$ & $\left.\begin{array}{l}4.11 \pm 0.24(6) \\
4.03 \pm 0.05(2) \\
4.20 \pm 0.18(6) \\
4.28 \pm 0.12(6) \\
4.22 \pm 0.13(6) \\
4.31 \pm 0.11(6) \\
3.76 \pm 0.06(3) \\
4.18 \pm 0.12(4) \\
3.92 \pm 0.05(24) \\
3.10 \pm 0.13(6) \\
2.03 \pm 0.12(4) \\
2.40 \pm 0.11(3) \\
2.85 \pm 0.03(2) \\
0.98 \pm 0.20(4)\end{array}\right\}$ & $\begin{array}{l}\text { Cystine } \\
\text { and } \\
\text { methio- } \\
\text { nine }\end{array}$ \\
\hline $\begin{array}{l}\mathrm{SB}_{\mathrm{I}} \\
\text { Soya-bean meal } \\
\mathrm{SB}_{5} \\
\text { Dried peas } \\
\text { Isolated soya protein } \\
\text { (Drackett) } \\
\mathrm{GN}_{\text {I } 2} \\
\mathrm{GN}_{\text {I } 8} \\
\mathrm{SB}_{3} \\
\mathrm{GN}_{\text {I I }}\end{array}$ & $\begin{array}{ll}77 \cdot 9 \pm 0.86 & 90.9 \pm 0.64 \\
76 \cdot 6 \pm 1 \cdot 54 & 9 \mathrm{I} \cdot 9 \pm 0.49 \\
74 \cdot 0 \pm 0.86 & 92 \cdot 0 \pm 0.64 \\
66 \cdot 1 \pm 3 \cdot 29 & 92 \cdot 2 \pm 2.87 \\
65 \cdot 2 \pm 0.86 & 97 \cdot 3 \pm 0.8 \mathrm{I} \\
& \\
62 \cdot 7 \pm 0.72 & 92 \cdot 3 \pm 0.49 \\
58.9 \pm 0.72 & 92 \cdot 4 \pm 0.49 \\
57 \cdot 4 \pm 0.86 & 90.4 \pm 0.64 \\
56 \cdot 5 \pm 0.72 & 92 \cdot 2 \pm 0.49\end{array}$ & $\begin{array}{l}70 \cdot 8 \\
70 \cdot 4 \\
68 \cdot 1 \\
60 \cdot 9 \\
63 \cdot 4 \\
57 \cdot 9 \\
54 \cdot 4 \\
51 \cdot 9 \\
52 \cdot 1\end{array}$ & $\begin{array}{l}59 \cdot 7 \pm 0 \cdot 50(2) \\
60 \cdot 4 \pm 2 \cdot 62(5) \\
58 \cdot 8 \pm 1 \cdot 15(2) \\
47 \cdot 9 \pm 2 \cdot 84(3) \\
46 \cdot 9 \pm 0 \cdot 85(2) \\
47 \cdot 1 \pm 1 \cdot 15(2) \\
42 \cdot 4 \pm 1 \cdot 95(2) \\
47 \cdot 5 \pm 1 \cdot 25(2) \\
38 \cdot 8 \pm 2 \cdot 00(3)\end{array}$ & $\begin{array}{l}3.57 \pm 0.02(2) \\
3.36 \pm 0.14(5) \\
3.57+0.10(2) \\
3.01 \pm 0.14(3) \\
2.70 \pm 0.09(2) \\
2.72 \pm 0.06(2) \\
2.37 \pm 0.06(2) \\
2.77 \pm 0.08(2) \\
1.97 \pm 0.10(3)\end{array}$ & $\begin{array}{l}\text { Methio- } \\
\text { nine }\end{array}$ \\
\hline $\begin{array}{l}\text { MM } 20 \text { (feather-meal) } \\
\text { Wheat gluten }\end{array}$ & $\begin{array}{ll}57 \cdot 2 \pm I \cdot 77 & 74 \cdot 3 \pm 0.88 \\
56 \cdot 4 \pm I \cdot 31 & 95 \cdot 9 \pm 0.60\end{array}$ & $\begin{array}{l}42 \cdot 5 \\
54 \cdot I\end{array}$ & $\begin{array}{l}33^{\cdot 1} \pm 2 \cdot 82(4) \\
45 \cdot 3 \pm x \cdot 00(4)\end{array}$ & $\left.\begin{array}{l}1 \cdot 70 \pm 0.14(4) \\
2 \cdot 78 \pm 0.08(4)\end{array}\right\}$ & $\begin{array}{l}\text { Methio- } \\
\text { nine and } \\
\text { lysine }\end{array}$ \\
\hline $\begin{array}{l}\text { Soya-bean meal }+2 \mathrm{~g} \\
\text { DL-methionine/ } 6 \mathrm{~g} \mathrm{~N}\end{array}$ & $88 \cdot 0 \pm I \cdot 54 \quad 92 \cdot 6 \pm 0.49$ & $8 I \cdot 5$ & $75 \cdot 2 \pm 1 \cdot 50(2)$ & $4.03 \pm 0.08(2)$ & $\begin{array}{l}\text { ? Isoleu- } \\
\text { cine and } \\
\text { valine }\end{array}$ \\
\hline $\begin{array}{l}\mathrm{SF}_{2} \\
\mathrm{SF}_{3} \\
\mathrm{SF}_{1}\end{array}$ & $\begin{array}{ll}75.0 \pm 0.89 & 90.5 \pm 0.46 \\
74.5 \pm 0.89 & 89.4 \pm 0.46 \\
69.5 \pm 0.89 & 88.1 \pm 0.46\end{array}$ & $\begin{array}{l}67 \cdot 9 \\
66 \cdot 6 \\
6+\cdot 2\end{array}$ & $\begin{array}{l}60 \cdot 1 \pm 0 \cdot 40(3) \\
64 \cdot 4 \pm 1 \cdot 88(4) \\
57 \cdot 2 \pm 1 \cdot 96(4)\end{array}$ & $\begin{array}{l}3 \cdot 20 \pm 0.10(3) \\
3.47 \pm 0.12(4) \\
3.14 \pm 0.10(4)\end{array}$ & $\begin{array}{l}\text { Cystine } \\
\text { and } \\
\text { lysine }\end{array}$ \\
\hline $\begin{array}{l}\text { CM } 49 \\
\text { Linseed cake } \\
\text { CM I } 9 \\
\text { CM I3 } \\
\text { 'Stored' milk }\end{array}$ & $\begin{array}{ll}77 \cdot 7 \pm \mathrm{I} \cdot 75 & 87.5 \pm 0.65 \\
76 \cdot 4 \pm 3.29 & 83.5 \pm 2.87 \\
75 \cdot 5 \pm \mathrm{I} \cdot 75 & 80 \cdot 9 \pm 0.65 \\
59 \cdot 4 \pm \mathrm{I} \cdot 75 & 7 \mathrm{I} \cdot 8 \pm 0.65 \\
59 \cdot 0 \pm \mathrm{I} \cdot 65 & 9 \mathrm{I} \cdot 9 \pm 0.58\end{array}$ & $\begin{array}{l}68 \cdot 0 \\
63 \cdot 8 \\
61 \cdot 1 \\
42 \cdot 7 \\
54 \cdot 8\end{array}$ & $\begin{array}{l}66 \cdot 9 \pm 2 \cdot 32(3) \\
67 \cdot 1 \pm 3 \cdot 98(6) \\
61 \cdot 7 \pm 1 \cdot 85(2) \\
50 \cdot 3 \pm 0 \cdot 70(2) \\
55 \cdot 0 \pm 5 \cdot 28(4)\end{array}$ & $\left.\begin{array}{l}3.68 \pm 0.20(3) \\
3.55 \pm 0.20(6) \\
3.49 \pm 0.25(2) \\
2.91 \pm 0.13(2) \\
3.12 \pm 0.18(4)\end{array}\right\}$ & Lysine \\
\hline
\end{tabular}

* Mean values with their standard errors for twelve values obtained on individual rats.

$\uparrow$ Mean values with their standard errors. Figures in parentheses show number of replicates.

$\ddagger$ Calculated from data of Block \& Mitchell (1946-7). 
limiting in the test protein; for a complete protein (egg) or when methionine, alone or with cystine, was limiting, the body-water method gave consistently lower results than the balance-sheet method. Dreyer (1960, and personal communication) has pointed out that the body-water method makes no allowance for differences in endogenous $\mathrm{N}$ losses that will be higher on a diet of normal protein content than on a protein-low diet, and that consequently the method may be expected to give low values relative to the balance-sheet method. Another possibility is that unavoidable losses in the collection of excreta lead to cumulative errors in a balance experiment that tend to exaggerate the extent of $\mathrm{N}$ retention (cf. Becker \& Harnisch, I958). Bender (I960) has published evidence that suggests that the sensitivity of the method may be affected by the limiting amino acid in a given protein. He determined the NPU of amino acid mixtures from which single acids were omitted. The theoretical value of $o$ was observed only when valine (mean 3 , range $0-8$ ) or methionine and cystine (mean 7 , range 0-17) were omitted; omission of lysine gave a mean value of 30 (range 17-39). With other deficiencies of essential amino acids the mean values ranged from I I to 21 . Although corresponding values by the balance-sheet method are not available, the observation of a higher NPU in the absence of lysine than in that of other essential amino acids indicates that when lysine is limiting a relatively high NPU may be obtained. The agreement found by us between the results by the two methods when lysine was the primary limiting amino acid may thus be accounted for.

Our findings on the differences between NPV and NPU support those of other workers. Thus Rippon (1959) and Tomarelli et al. (1959), respectively, found lower values for casein and wheat gluten and for human and cow's milk by carcass analysis than by the balance-sheet method. de Muelenaere \& Quicke (1959) and Forbes \& Yohe (1955), respectively, noted agreement for maize proteins and blood fibrin. The limiting acids for the two latter proteins are lysine and isoleucine respectively (Block \& Mitchell, $1946-7$ ). When isoleucine and leucine were omitted from a mixture of essential amino acids Bender (1960) observed a mean NPU of 20 (range $7^{-27}$ ) instead of the theoretical value of $\mathrm{o}$. Consequently when one, or both, of these acids are limiting the protein may still have a relatively high NPU.

It can be seen from Table 4 that, in general, the error of the body-water method is higher than that of the balance-sheet method, a finding in agreement with that of other workers (Forbes \& Yohe, 1955; Dreyer, 1957). A disturbing feature of the former method is the wide variation observed between replicates with the same protein and between mean values reported from different laboratories for the same or similar proteins. Bunyan \& Price (1960) report NPU values for a number of protein preparations including vitamin-low casein (Genatosan Ltd) and the ARC meat and fish meals studied by us. For two samples of the casein we found mean values of $7 \mathrm{r}^{\circ} \mathrm{O}$ (range 60.6-76.8 for twenty-four replicates) and $7 x^{\cdot 2}$ (range $58 \cdot 3-78 \cdot 9$ for twelve replicates) whereas Bunyan \& Price's (1960) mean value was 53 for four replicates. Mean values (two to four replicates) found by us and by Bunyan \& Price (I960) respectively for the meat and fish meals were: MM 20, 33 and 34; MM I0, 19 and 14 ; $\mathrm{MM} \mathrm{I}_{1}, 43$ and $31 ; \mathrm{FM}_{4}, 34$ and $24 ; \mathrm{FM} 6,7 \mathrm{I}$ and $59 ; \mathrm{FM} \mathrm{I} 7,47$ and 22 . In all of our tests casein was included as reference protein (p. 127) as it was hoped that the variation 
between replicates for other proteins might be reduced by referring them to an arbitrary value of 100 for casein. However, this method of expressing the results increased rather than reduced differences between replicates. These findings indicate that, because of these wide variations, two replicates, even if they agree, may not be sufficient to give a satisfactory assessment.

Our experiments show that, under normal conditions, there is good correlation between results obtained by the balance-sheet (NPV) and body-water (NPU and NPR) methods. The latter method involves fewer measurements but would require greater numbers of rats to attain an accuracy similar to that of NPV (cf. Forbes \& Yohe, 1955; Dreyer, 1957). Our results confirm the excellent correlation between NPU and NPR reported by Bender \& Doell (1957). These authors point out that whereas NPV and NPU are expressed on a percentage scale, NPR is not; using the correlation equation relating NPU to $\mathrm{NPR}$, they have calculated that $\mathrm{NPR} \times \mathrm{I} 6=\mathrm{NPU}$. They termed the resulting value protein retention efficiency (PRE). A similar calculation for our results gives a conversion factor of $I 8$. I which further emphasizes differences that may exist between rat colonies and the need to establish the necessary correlations in different laboratories before applying this method. de Muelenaere, Quicke \& Wessels (1960) established a regression equation relating water and $\mathrm{N}$ in the bodies of chicks and used it to determine the NPU of proteins in ten materials, which included three samples of maize previously assayed on rats (de Muelenaere \& Quicke, I959). The agreement between the rat and chick results was good. In view of the high correlation between NPU and NPR, de Muelenaere, Quicke \& Wessels (I960) suggest that the simpler determination of NPR might be used instead of that of NPU; our results with rats and those of Bender \& Doell (1957) support this view.

\section{SUMMARY}

I. The method of Miller \& Bender (I955) for assessing the nutritive value of proteins by relating body water to body nitrogen in the rat has been studied. The method has been applied to thirty-five protein preparations that had been assayed by the balance-sheet method.

2. In confirmation of the findings of other workers, the ratio of $\mathrm{N}$ to water in the body increased significantly with the age of the rat. The ratio was slightly, but significantly, higher for female than for male rats. Equal numbers of each sex were, therefore, used in all subsequent tests.

3. Bodies of rats given a stock diet had a slightly, but significantly higher concentration of water than those of litter-mates given 'protein-free' or $8 \%$ protein diets; the concentration of body $\mathrm{N}$ was not affected.

4. There was no correlation between the age and the ratio of $\mathrm{N}$ to water in the liver of rats given a stock diet. The concentration of $N$, but not that of water, in the liver increased significantly with increasing concentration of protein in the diet.

5. The significance of these observations is discussed in relation to the findings of other workers. The need to establish the necessary correlations for individual rat colonies before applying the method is stressed. 
6. The net protein value (NPv $=$ biological value $\times$ true digestibility $\div$ Ioo) determined by the balance-sheet method and the net protein utilization (NPU) assessed by the measurement of body water were highly correlated $(r=0.91)$ for the thirty-five protein preparations tested.

7. Numerical agreement between NPV and NPU was good for those proteins in which lysine or lysine with cystine were the limiting amino acids. NPV was invariably higher than NPU when no acid was limiting (egg) or when methionine, alone or with cystine, was limiting. The significance of these findings, which are in agreement with those of other workers, is discussed.

8. The error of the body-water method was greater than that of the balance-sheet method, an observation that has been previously made in other laboratories.

We are grateful for the assistance given by Miss M. V. Chapman in the care and feeding of the animals and by Mrs M. R. Hussey with the analytical work.

\section{REFERENCES}

Adrian, J. \& Rerat, A. (1958). Ann. Nutr., Paris, 12, no. 2, Techniques, p. I.

Allison, J. B. (1955). Physiol. Rev. 35, 664.

Becker, M. \& Harnisch, S. (1958). Arch. Tierernähr. 8, 420.

Bender, A. E. (1958). Proc. Nutr. Soc. 17, 85 .

Bender, A. E. (1960). Clin. chim. Acta, 5, 1.

Bender, A. E. \& Doell, B. H. (1957). Brit. F. Nutr. Ir, 140.

Bender, A. E. \& Miller, D. S. (1953). Biochem. F, 53, vii.

Block, R. J. \& Mitchell, H. H. (1946-7). Nutr. Abstr. Rev. r6, 249.

Boyne, A. W., Carpenter, K. J. \& Woodham, A. A. (1961). F. Sci. Fd Agric. 12, 832.

Bunyan, J. \& Price, S. A. (1960). F. Sci. Fd Agric. rI, 25.

Chapman, D. G., Castillo, R. \& Campbell, J. A. (1959). Canad. F. Biochem. Physiol. 37, 679.

de Loureiro, A. (1931). Arch. Pat., Lisboa, 3, 72.

de Muelenaere, H. J. H. \& Quicke, G. V. (1959). S. Afr. F. agric. Sci. 2, 515.

de Muelenaere, H. J. H., Quicke, G. V. \& Wessels, J. P. H. (1960). S. Afr. F. agric. Sci. 3, 9r.

de Muelenaere, H. J. H., Rayner, A. A. \& Muller, E.-R. (1960). S. Afr. F. agric. Sci. 3, 53 I.

Dreyer, J. J. (1957). Brit. $\mathscr{F}$. Nutr. I1, 22.

Dreyer, J. J. (1960). Proc. Nutr. Soc. Sth. Afr. 1, 57.

Duckworth, J., Woodham, A. A. \& McDonald, I. (1961). F. Sci. Fd Agric. 12, 407.

Forbes, R. M. \& Yohe, M. (1955). F. Nutr. 55, 493.

Henry, K. M., Cormack, R. M. \& Kosterlitz, H. W. (196r). Brit. F. Nutr. 15, I99.

Henry, K. M. \& Kon, S. K. (1952). F. Dairy Res. 19, 2 I6.

Henry, K. M. \& Kon, S. K. (I956). Brit. F. Nutr. ro, 39.

Henry, K. M., Kon, S. K., Lea, C. H. \& White, J. C. D. (1947-8). F. Dairy Res. 15, 292.

Henry, K. M., Kon, S. K. \& Watson, M. B. (1937). Milk and Nutrition, Part I, p. 37. Reading: National Institute for Research in Dairying.

Henry, K. M., Kosterlitz, H. W. \& Quenouille, M. H. (1953). Brit. F. Nutr. 7, 5 I.

McKinlay, H. (195 I). F. Anim. Tech. Ass. 2, no. 2, p 2.

Miller, D. S. \& Bender, A. E. (1955). Brit. F. Nutr. 9, 382.

Mitchell, H. H. (1923-4). F. biol. Chem. 58, 873 .

Mitchell, H. H. \& Carman, G. G. (1926). F. biol. Chem. 68, 183.

Mitchell, H. H. \& Villegas, V. (1923). F. Dairy Sci. 6, 222.

Osborne, T. B., Mendel, L. B. \& Ferry, E. L. (1919). F. biol. Chem. 37, 223.

Rippon, W. P. (1959). Brit. F. Nutr. 13, 243.

Rutger's University: Bureau of Biological Research (1950). Co-operative Determinations of the Amino Acid Content, and of the Nutritive Value of Six Selected Protein Food Sources 1946-1950. New Brunswick, N.J.: Rutger's University (Mimeo).

Tomarelli, R. M., Minnick, N., d'Amato, E. \& Bernhart, F. W. (1959). Ұ. Nutr. 68, 265. 